\title{
Playing and Traditional Games in Learning Model Based on Culture of National Character and Play
}

\author{
Euis Kurniati, Indrawati Noor Kamila, Rudianto, Cucu Eliyawati \\ Universitas Pendidikan Indonesia, Setiabudhi, Bandung, Indonesia \\ Corresponding e-mail: euiskurniati@upi.edu
}

\begin{abstract}
Playing is a part that cannot be separated from a children's world. Playing has a positive role for the development of the child. One form of playing activities in kindergarten is through games, including traditional games. There are various implementations of traditional playing activities and games conducted in the school including through the development of learning model based on the culture of national character and play (BKKB). This article discusses about how and by what means playing activities applied in BKBB learning model as well as any traditional game that can be applied in this model. Based on the review, it can be seen that playing in learning BKKB model serves as the main activity. Playing is designed for learning. It means that all activities done by the children at school should meet the characteristics of a playing that is fun, spontaneous, voluntary, intrinsic motivation. In BKBB learning model, the children have the opportunity to choose the activities, playing is also done through group activities, although in practice it can be implemented individually. In connection with the traditional games, it is designed and implemented every day. The traditional game is one form of games which is designed in BKBB learning model. In this case, the various forms of traditional games can be played as an attempt to train children to obey rules. The traditional games that are particularly popular among children are Ucing-ucingan, Huhuian, Bebentengan, Sonlah, as well as other traditional games.
\end{abstract}

Keywords: $\quad$ playing, traditional games, BKBB learning model

\section{INTRODUCTION}

Playing is identified by experts as the job of children (Schaefer,dkk., 2011; Gordon \& Browne, 2005). Play is an important and complex topic in relation to children's development (Ridgway \& Quinones, 2012). Playing is an activity that has the characteristics of voluntary, intrinsic motivations, flexible in choosing in determining how the activity will be performed (Schaefer, dkk., 2011). Ginsburg (2007) explains that play is a cherished part of childhood that offers children important developmental benefits and parents the opportunity to fully engage with their children. Ashiabi (2007) review suggests that play is beneficial to children's socioemotional development. Bailey, R. (2002) also argued that play is a fundamental medium for acquiring social skills. In addition, Garvey, Schaver
\& Reid (2011) state that playing is seen as a behavior that comes naturally to be found in human and animal life, playing is also intrinsically driven by the desire to have fun. Meanwhile Hildebrand (Moeslichatun, 1996) argues that playing means to explore, manipulate, repeat any exercises that can be done to transform imaginatively things in common with the world of adults. Some sense to play it can be deduced, play is important, complex, arise from intrinsic motivations, and do with gladness.

Activities that are done by children when playing will affect all aspects of their development, but in fact the school put more emphasis on activities that are pencil-book-test compared to using playing as the main activity (Nicolopoulou, 2010). Huang (2013) also states that in China alone, $65 \%$ of parents place more emphasis on the importance of activities related to academic skills such as reading, writing and arithmetic compared to playing. The above analysis has similar conditions with what 
happened in Indonesia, where the school organization for early childhood education focuses on academic mastery, considering these skills are easier to measure. According to research conducted by Istiyani (2013), in schools children tend to be focused on reading, writing and arithmetic and with a less precise method of delivery, this happens because of the expectations of parents who want their children to have the ability to read, write and calculate more quickly than others. Whereas reading, writing, and arithmetic on ECD should only be introduction of letters, numbers with a simple concept, gradually, and through playing which is a fun learning for children (Pratiwi, 2015).

Is playing important? If educators are asked about it, then they will say YES. But how to implement them in learning will be very diverse, some of which are carried out through the game. Santrock (1995) explains that game is a fun activity that is undertaken for the sake of the activity itself. A game is an activity in which playing has to have clear rules and agreed on. Dockett \& Fleer (2000) explains that at about the time children start school, games become important. Games are characterized by the explicitness of rules and by the imposition of some form of sanction if the rules are broken. Hoorn (1993) states that games with rules play are games that involve loyalty and commitment to the rules of the game and have been agreed upon together. In this game the rules must be approved by each player before the game start. One of the activities that is currently recommended to be reintroduced to children at school is traditional game activities.

The suggestion to reintroduce traditional games to children in schools is due to the changing lifestyles of traditional life towards modern life (the era of technology). The development of increasingly modern technology today helped changing the game options of children and adolescents from the traditional game switched to modern games such as online games, video games, and others (Batiar, 2013). It is called a modern game because the game is played using sophisticated equipment with cutting edge technology, which is very different when compared to traditional games (Nur, 2013). Some research on the modern game shows that there are negative effects of the modern game to the development of children, especially social skills. Gentile, Lynch, Linder \& Walsh (2004) state that electronic games affect aggressive behavior such as arguing and hostile.

On the other hand the traditional game shows a lot of benefits. The results of research conducted by Kurniati (2016) states that the traditional game has a great opportunity to develop the social skills of children. The traditional games are identified in research carried out by at least two players, generally a number of games can be done without player limitation. This provides an opportunity for the players to interact, communicate, and collaborate in carrying out the game. The traditional game is also an active game, meaning that players actively involved both physically and mentally. They move, imagine, being creative while sharpening their social intelligence. This shows the role of traditional games in all aspects of child development.

But along with the change in the social environment around the child, also with changing times traditional games that are used to be played by children, are now beginning to be abandoned. Children prefer games in mobile phones, video games, or on tablets than traditional games (Batiar, 2013). Based on the statement above, it takes a proper formulation of the school to provide educational services for early childhood development by optimizing traditional play activities and games in kindergarten.

One of the efforts to apply traditional playing activities and games in the learning process is through the development of learning model that accommodates its characteristics. Learning model based on the culture of national character and play (BKBB) is one of the models that accommodate it (Kurniati, 2015). However, how and in what way the traditional game playing activities and BKBB learning model accommodate it is in need of further review. Thus, this article is focused on the study about playing and traditional games in BKBB learning model.

\section{THE URGENCY TO PLAY IN BKBB LEARNING MODEL}

Huizinga (1980) explains that humans are creatures that play (homo ludens). Playing can be done either individually or in groups. According to Piaget, 1962; Schwartzman, 1978; Vygotsky, 1978 (Ashiabi, 2007), the concept of play in early childhood development emerges the element of creativity, adaptation, exploration, experimentation, learning, communication, socialization, acculturation, and mastery. On the other hand, Coots (2009) states that playing is essential for children's development. Frank and Theresa Caplin (Hildebrand, 1986: 55-56) also suggest that there are sixteen playing values for children, including helping the growth and development of children. Meanwhile, Istiyani (2013) 
states that through play children can get to know the rules, socializing, placing themselves, managing emotion, tolerance, cooperation, succumbing, sportsmanship, and more positive attitudes. Given many benefits of playing for the growth and development of children, Holis (2016) states that the use of playing in the program implementation of in kindergarten is an absolute requirement that absolutely cannot be ignored.

With reference to the many benefits of playing for the growth and development of children, then it becomes the foundation to develop BKBB learning model based on playing and it intends to restore early childhood development to world of playing, so when there is academic activity then the implementation will be done through playing. Kurniati (2015) states that Learning Model Based on the Culture of National Character and Play (BKBB) in kindergarten is defined as a general pattern of educational services provided by the teacher to the learner by using a group setting which is based on the richness of the culture, the value of the nation's character and concept and characteristics of play which aims to help learners develop character (special), and stimulated the development of the child (general) in order to achieve optimal development. This learning model, developed since 2013 has been tested on various school in Bandung, West Bandung, Cimahi, Sumedang District, Indramayu District, Majalengka and Cirebon District.

In the BKBB model guide book which was developed by Kurniati (2015) it explains that:

In BKBB learning model, children's playing activities were divided into seven group plays, which consists of: (1) Free Play Group, (2) Guided Play Group (Traditional Games), (3) Constructive Play Group, (4) Role Pay Group, (5) Play Group of Numbers and Letters, (6) Handcraft Play Group, and (7) Reading Play Group. The play group in BKBB model is interpreted as the main activity center which is set in a group, where each group play has a different activity. Group play consists of a kind/type of play that is usually done by children age 4-6 years. Although the activities are in group, but the goals are individual on the children themselves. This means that children have the freedom to do activities, either individually or together. In the group of children playing can explore activities appropriate to the type of playing activities. Below is the explanation of play group:

\subsection{Free Play Group}

Free Play Group means that the child has the freedom to determine his/her activities. This play group is generally conducted in the school yard or playground area. The main activities are undertaken to further explore gross motor activity through active playing. Activities undertaken in this group includes climbing, jumping, running, and romping, playing bike, soccer, jump rope, sand, and perform acrobatic tricks. Nevertheless, the play group did not rule out the possibility that the children are also training their soft skills and other development aspects.

\subsection{Guided Play group (traditional games)}

Guided Play Group is guided playing activities that have a rule that has been identified and agreed upon in advance. This play group aims to introduce rules to children in ways that are fun. Games that can be performed on the main group are the traditional games. This play group can be led by the teacher as a facilitator in the activity.

\subsection{Constructive Play Group}

Constructive Play Group is the playing activities carried out by building or constructing a form. The activity in this group is blocks, lego, and puzzle too. It is generally done indoors.

\subsection{Role Play Group}

The Role Play Group is a role play activities done by pretending to be someone, something or to create a certain mood. In this activity, children are imagining a role which relate to other people, other objects of space, time and situation which are different from themselves. Imitation, imagination and dramatization is the whole part of playing the role that presents, replaces or portrays the actual experience with the use of symbols, language, and social skills appropriate to their level of development.

\subsection{Group Play of Numbers and Letters}

Group Play of Numbers and Letters aimed to introduce academic skills (numbers and letters) to early childhood development. This activity was carried out in preparation for the child to follow the 
next level. The activities in this group is a game of numbers, letters, words, and forms that can be done with a variety of media such as computers, electronic equipment, literacy, math and science games.

\subsection{Handcraft Play Group}

In this play group, children create something that is a result of their own work. The activities undertaken put more emphasis on the activities related to art and creativity. Children can use paint, threads, beads, magic makers, scissors, large crayons, pencils, glue, etc. to make crafts.

\subsection{Reading Play Group}

Pre-schoolers love looking at books and like it when adults read. 4 years old children like strange and funny, wild, dramatic and fantastic stories (including legends), animal books, poems, and stories about everyday life, also some factual books. 5 and 6 years old children generally prefer a more realistic and credible books, poetry, holiday stories, and comics as well as books about scary and magical things.

\section{TRADITIONAL GAME CONTENT IN BKBB LEARNING MODEL}

One of the activities that are designed to play in BKBB learning model is traditional games in the guided play group. Cooney (1999) states that traditional play forms are those activities handed down from one generation to the next and continuously followed by most people (Ulker \& GU, 2004). In harmony with the above explanation, Kurniati (2016) states that:

"Traditional game is a playing activity that grows and develops in a certain area, which is full of cultural values and values of community life and hereditary taught from one generation to the next. From this game, children will be able to develop their potential, gain useful and meaningful experience, to be able to build relationships with their peers, increase vocabulary, and be able to express the suppressed feelings while preserving and love the culture of the nation."

In BKBB learning model traditional game are performed on the guided play step. This step is aimed at keeping the child in known of the rules through playing. Considering that in free play activities children are free to choose whatever activity they want to do, traditional game trains children to be able to comply with the rules and know the limits available in the environment. In addition, the traditional game activities in this model also aim to introduce the nation's cultural values in ways that are fun.

Traditional game is very much in accordance with children development and it can teach other skills (Ulker \& Gu, 2004). Traditional games require players to be more active and committed. The game is also commonly performed by two or more people. More participants involved in the game then it would be more fun. It encourages the establishment of interaction, communication, and cooperation among the participants of the game.

The traditional game designed in $\mathrm{BKBB}$ learning model is common game in the neighbourhood/area respectively. Although some areas has the same game but with a different name, such as dakhon (tribal Java) and congklak (Sundanese tribe). In the area of West Java alone, there are various types of games such as Huhuian, Bebentengan, Sonlah and ucing-ucingan which has many variations like ucing Sumput, ucing yarn, ucing sculpture, ucing baledog and other games (Kurniati, 2016).

\section{DISCUSSION}

Playing activities in BKBB learning model are implemented by dividing the game into seven groups play. Each group has to play different types of playing activities. It is projected to be able to stimulate all aspects of child development. In this model the type of play is divided into two, namely playing outside and inside the classroom. Santoso (2006) states that game can be played in the classroom or outside the classroom. The game should have value assorted to it to develop all aspects of the personality or children potential. Games related to the fine motor skills can be done indoors, while games related to gross motor mostly done outdoors. In BKBB model children explore the first game outside of the classroom to practice physical-motor development, especially gross motor and other developmental aspects, afterward continued to play indoors activities more related to academic skills. Structuring the child's learning environment to encourage them to be willing to engage in various activities both inside and outside the room is very important, so that the child will be happy (Rusthton, et al., 2009). Outdoor playing 
activities are designed for learning and are carried out at the beginning of activities to encourage children to be more independent and physically active. Playing related to physical activity will have an impact on the level of fitness and health of the child (Fletcher, et al., 2011).

In connection with playing activities in the classroom, in BKBB learning model children have the opportunity to choose activities. The game choosing activities are designed on the choice time step. One of the characteristics of play is voluntary in choosing activities (Schaefer, 2011). However, every child is basically advised to follow all the activities that have been prepared. At this step the child can develop various aspects of its development through constructive activities, numbers and letters, feet work, reading and role playing.

In the BKBB learning model playing are conducted through group activities, although in practice it can be implemented individually. Child interaction in group activities will be able to build positive relationships with their peers. Mulyadi (2004) states that playing with peers make children learn to build a social relationship with other children who they had not met and overcome the various problems posed by the relationship.

Traditional gaming activities performed in BKBB learning model, is one effort to train children to obey the rules, because, although the child is given freedom in choosing activities to play, they still have to be taught about the restrictions and rules. In addition, the traditional game activities are also carried out to preserve the national culture and build the character of children. This was carried out considering the fact that children do not play traditional game that much anymore. The activity shift happens more so when innovation in technology increasingly widespread. But apparently this shift in the traditional game activities does not only happen in Indonesia. It also occurs in the United States, China, Japan and other countries. Huang, 2013, states that long ago, children in China used to play more on the outside house with their friends like just playing hide and seek and catching fish in the river. It is also common in Japan, where $65 \%$ of school age children spend after school playing at their home or at a friend's house (Report of the 1st Basic Survey on Conditions of Children's Daily Lives, 2005). Video and online games are not the kind of game that is important in the game that they do, and they prefer the traditional games such as kendama (cup and ball), koma (tops), otedama (beanbag juggling), takeuma (stilts), tako-age (kite flying), ayatori (cat's cradle) (Hiroaki, tt). These conditions encourage the school to be a medium for children to recognize traditional games that are infused with the values of the culture of a nation.

\section{CONCLUSIONS}

Playing is the main activity in early childhood. In the BKBB learning model playing activities are designed and integrated in learning procedure. This model has seven game groups that can be used as a medium to develop all aspects of child development. Traditional gaming activities are part of the playing activities in BKBB learning model, an effort to train rules/restrictions/commitment and an effort to preserve the nation's cultural values. Given the importance of playing activities and traditional games in learning in kindergarten, it requires the school requires to provide facilities and to make the arrangement of the right environment so that the needs and rights of children to play can be met. In order to optimize playing activities and traditional games in the learning process, the teachers need to be creative as the steering committee, controller and executor of education in early childhood development. BKBB learning model can be one of the solutions in order to restore early childhood development institutions according to its function as a place to play, having a lot of new friends in a pleasant atmosphere.

\section{REFERENCES}

Ashiabi, G. S. (2007). Play in the preschool classroom: Its socioemotional significance and the teacher's role in play. Early Childhood Education Journal,35(2), 199-207.

Bahtiar, N. (2013). Dampak Teknologi Permainan Modern Terhadap Kehidupan Anak dan Remaja di Kompleks Bumi Tamalanrea Permai (BTP) Makassar. Skripsi. Universitas Hasanuddin Makasar: FISIP.

Bailey, R. (2002). Playing social chess: Children's play and social intelligence.Early Years: An International Journal of Research and Development, 22(2), 163-173.

Coots, N. M. (2009). Perceptions and Practical Implications of Play at School. Tesis. The Evergreen State College.

Docket, S. \& Fleer, M. (2000). Play and Pedagogy in Early Childhood: Bending the Rules. Australia: Harcourt Publisher International.

Fletcher, R. dkk. (2011). Fathers' perceptions of rough-and-tumble play: implications for early 
childhood services. Australasian Journal of Early Childhood, 36(4), 131.

Gentile, D. A. dkk. (2004). The effects of violent video game habits on adolescent hostility, aggressive behaviors, and school performance. Journal of adolescence, 27(1), 5-22.

Ginsburg, K. R. (2007). The importance of play in promoting healthy child development and maintaining strong parent-child bonds. Pediatrics, 119(1), 182-191.

Gordon, AM. \& Browne, KW. (2005). Beginnings and Beyond (Foundations of early childhood educations:8th editions). USA: Wadsworth.

Holis, A. (2016). Belajar Melalui Bermain untuk Pengembangan Kreativitas dan Kognitif Anak Usia Dini. Jurnal Pendidikan Universitas Garut, 09(1), 23-37.

Hoorn, N. A. (1993). Play at The Center of the Curriculum. New York: Macmillan Publishing Company.

Huang, R. (2013). What can children learn through play? Chinese parent's perspective of play and learnn in early childhood education. Te Iti Kahuragi School of Education e-Journal, 1, 12-19.

Huizinga, J. (1980). Homo Ludens A Study of Play Element in Culture. London, Boston, \& Henley: Routledge \& Kegan Paul.

Istiyani, D. (2014). Model Pembelajaran Membaca Menulis Menghitung (Calistung) pada Anak Usia Dini di Kabupaten Pekalongan. Jurnal Penelitian, 10(1), 1-18.

Kurniati, E. (2015). Model Pembelajaran Berbasis Budaya, Karakter Bangsa dan Bermain di Taman Kanak-kanak. Prosiding Seminar nasional Pendidikan Anak Usia Dini. Bandung: 8-9 Mei 2015.

Kurniati, E. (2016). Permainan Tradisional dan Perannya dalam Mengembangkan Keterampilan Sosial Anak. Jakarta: Prenada Media Kencana.

Moeslichatoen. (1996). Metode Pengajaran di Taman Kanak-Kanak. Jakarta: Departemen Pendidikan dan Kebudayaan.

Mulyadi, S. (2004). Bermain dan Kreativitas. Jakarta: Papas Sinar Sinanti.

Nicolopoulou, A. (2010). The alarming disappearance of play from early childhood education. Human development, 53(1), 1-4.

Nur, H. (2013). Membangun Karakter Anak Melalui Pemainan Anak Tradisional. Jurnal Pendidikan Karakter, 3(1), 88-94.

Pratiwi, E. (2015). Pembelajaran Calistung Bagi Anak Usia Dini antara Manfaat Akademik dan
Resiko Menghambat Kecerdasan Mental Anak. Universitas Muhammadiyah Ponorogo: Prosiding Seminar Nasional Pendidikan.

Ridgway, A. \& Quinones, G. (2012). How Do Early Childhood Students Conceptualize Play-Based Curriculum?. Australian Journal of Teacher Education, 37(12), 1-12.

Rushton, S. J. R. A. \& Larkin, E. (2009). Neuroscience, Play and Eraly Education: Connetions and Assessment. Springer Science Business Media, LLC 2009. Published online 21 November 2009.

Schaefer, DR., dkk. (2011). The contribution of extracurricular activities to adolescent friendships: New insights through social network analysis. Jurnal Developmental psychology, 47(4), 1141.

Santoso, S. (2006). Optimalisasi Tumbuh Kembang Anak Usia Dini Menuju Anak yang Sehat dan Cerdas Melalui Permainan. Jurnal Pendidikan Penabur, 7(5), 93-99.

Santrock, J.W. (2002). Life Span Development (Perkembangan Masa Hidup). Jakarta: Erlangga

Ulker, R. \& Gu, W. (2004). Traditional Play: Chinese and Turkish Examples. TASL Conference in Atlanta, Georgia, 20 February 2004 